\title{
Effect of Green Construction on a Building's Carbon Emission and Its Price at Materialization
}

\author{
Shuangxi Zhou ${ }^{1}$, Zhenzhen Guo ${ }^{1}$, Yang Ding ${ }^{2, *}$, Jingliang Dong ${ }^{1, *}$, Jianming Le $^{1}$ and Jie Fu ${ }^{1}$ \\ 1 School of Civil Engineering and Architecture, East China Jiaotong University, Nanchang 330013, China; \\ green.55@163.com (S.Z.); guozhenzhen0823@163.com (Z.G.); jmle@sina.com (J.L.); Fulljoy@foxmail.com (J.F.) \\ 2 Department of Civil Engineering, Zhejiang University, Hangzhou 310058, China \\ * Correspondence: ceyangding@zju.edu.cn (Y.D.); dongjingliang@ecjtu.edu.cn (J.D.); \\ Tel.: +86-130-2720-5892 (Y.D.); +86-199-0700-8997 (J.D.)
}

Citation: Zhou, S.; Guo, Z.; Ding, Y.; Dong, J.; Le, J.; Fu, J. Effect of Green Construction on a Building's Carbon Emission and Its Price at Materialization. Sustainability 2021, 13, 642. https://doi.org/10.3390/ su13020642

Received: 4 December 2020 Accepted: 5 January 2021 Published: 12 January 2021

Publisher's Note: MDPI stays neutral with regard to jurisdictional clai$\mathrm{ms}$ in published maps and institutional affiliations.

Copyright: (C) 2021 by the authors. Licensee MDPI, Basel, Switzerland. This article is an open access article distributed under the terms and conditions of the Creative Commons Attribution (CC BY) license (https:// creativecommons.org/licenses/by/ $4.0 /)$.

\begin{abstract}
Buildings consume many resources and generate greenhouse gases during construction. One of the main sources of greenhouse gases is carbon emission associated with buildings. This research is based on the computing rule of carbon emission at the materialization stage. By taking the features of green construction into consideration, quantitative analysis on construction carbon emission was undertaken via Life Cycle Assessment (LCA). Making use of Vensim (a system dynamics software package), we analyzed the amount of carbon emission at the materialization stage and determined the major subsystems affecting the carbon emission, then took into comprehensive consideration the differences of each subsystem's carbon emission under different construction technologies. Under the mechanism of carbon trade at the materialization stage, the total price of carbon trades remains unchanged, while the trading price of each subsystem is adjusted. Under these conditions, a coefficient for step-wise increases in carbon price was proposed. By establishing such a system of gradient prices, construction companies are encouraged to adopt high-efficiency emission reduction technologies. Meanwhile, the system also provides a reference for the formulation of pricebased policies about buildings' carbon trading, and accelerates the process of energy conservation and emission reduction in China and the world at large.
\end{abstract}

Keywords: green construction; life cycle assessment (LCA); system dynamics; carbon trading prices

\section{Introduction}

The construction industry has boosted the development of the national economy at the expense of consuming a great quantity of natural resources and causing severe environmental pollution. China, as a big $\mathrm{CO}_{2}$ (carbon dioxide) producer, is now facing pressure to reduce emissions. Under the Paris Agreement, it was proposed to limit the global temperature rise to no more than $2{ }^{\circ} \mathrm{C}$ [1]. In 2018, the 6th Comprehensive Report of IPCC pointed out that the average global temperature over pre-industrial levels had already increased by $1{ }^{\circ} \mathrm{C}$ from $0.69{ }^{\circ} \mathrm{C}[2,3]$ in 2014 . These data indicate that more work should be done to push forward emission reduction. The huge global climate changes resulting from emission of greenhouse gases draws extensive attention from the international community. About $40 \%$ of energy annually consumed in the world is related to the construction industry. The amount of $\mathrm{CO}_{2}$ produced by the construction industry accounts for 36\% [4] of the global total. According to data from the 2018 China Statistical Yearbook, coal consumption in the construction industry was about 75.196 million tons (standard coal equivalent), an increase of $1.77 \%$ compared to the previous year. Additionally, building-construction-related energy consumption accounted for 20 to $30 \%$ of total energy consumption, exceeding the proportions of both industry and transportation consumption. China's carbon emissions are the largest in the world [5,6]. At the opening ceremony of the 21st UNCCC in Paris, President $\mathrm{Xi}$ announced that China would reach peak $\mathrm{CO}_{2}$ emission in around 2030. In the new 
landscape featuring harmonious development of people and nature, it is of key significance to take effective measures to reduce greenhouse gas emissions in the construction industry.

Since the 1990s, the assessment of buildings' carbon emission and its environmental impact is one of the hot spots for today's energy conservation and emission reduction agenda [7-9]. A large number of studies were conducted on the carbon emissions of buildings and the impact on the ecological environment at home and abroad. In terms of the carbon emission inventory framework system, the main focus is on life cycle impact assessment (LCA). Research into a buildings' carbon emission and its effect on the environment is common-at present, there are four methods of calculation of $\mathrm{CE}$, including the field measurement method, method of balance calculation between materials and products, emission coefficient method, and the model method [10]. Among these methods, the emission coefficient method is the most common. Li et al. [11], based on a footprint assessment standard, first proposed the use of a measurement model for carbon emission from building construction with the help of BIM (Building Information Modeling) and other relevant software. Yu et al. [12] concluded that, according to the life cycle theory residential buildings' carbon emission exert a greater effect on the environment during operation and maintenance as well as at the materialization stage. Zhang et al. [13,14] defined the accounting scope of a buildings' life cycle carbon emission based on the LCA theory. They also clarified the essence of low-carbon buildings, by conducting inventory analysis on carbon emission in different stages of a building's life circle, such as the materialized stage (construction process), the operation stage, the demolition stage, and the disposal stage. Wang et al. $[15,16]$ first put forward a calculation model for calculating a building's carbon emission in its building stage. This model was based on the basic norm of shift consumption per unit work volume and energy consumption per shift of shift cost norm in construction machines. Based on the LCA method, Gong et al. [17] evaluated the influence of three kinds of residential buildings on the environment. These three structures are the Beijing CFC, SFC, and WFC. The research results demonstrated that the main emission source of $\mathrm{CO}_{2}$ is power consumption. All studies mentioned above can precisely calculate a building's carbon emission at the materialized stage; however, the modeling and calculation process in these studies are complicated.

As an important market mechanism for controlling greenhouse gas emission, the carbon emission right trading is under implementation around the world. As carbon emissions are unavoidable during the construction phase of buildings, in response to the global low-carbon environmental protection order, the carbon emission trading system is used to control the carbon emissions generated during the materialization stage. The carbon emission policies are established according to resource allocation. These policies can encourage construction companies to make innovations around energy conservation and take relevant measures in construction processes to lower carbon emission. In 2002, the UK pioneered the world's first inter-enterprise carbon emission right trading system. Later in 2005, the EU established the first transnational system, EUETS (EU Emission Trading Scheme), providing important data and guidance for carbon emission trading on a global scale. Following the EU, the United States, Japan, and Australia started their own carbon emission trading systems. Similarly, China started its own carbon emission trading pilot in 2013. China officially launched carbon emission rights trading market in December 2017 [18]. Gao et al. [19] studied the determination and trading of carbon emission rights for green buildings. Zhao et al. [20] showed that the price of carbon-labeled products has a significant impact on consumers' purchasing behavior. Haites [21] indicated that carbon tax needs to be adjusted according to economic fluctuations for controlling carbon emissions. In general, when the building is of a different structural form, made of different items, or under different climate conditions, most studies on the building's carbon emission mainly focus on three aspects. First, the definition of the carbon emission calculation method; second, the application of the calculation method; third, the emission reduction potential. These studies fail to explore the interaction between the building's carbon emission and the existing carbon emission rights trading market. This article, based 
on the theories and methods of system dynamics, divided the materialized stage into six subsystems. Under the LCA theory, the carbon emission coefficient method is used with the aid of the system dynamics software Vensim, to analyze the carbon emissions during the building phase, and determine the main subsystems that affect carbon emissions. With the help of proprietary software, the amount of carbon emission at the materialization stage was analyzed and the subsystems that influenced the total carbon emissions the most were identified. Additionally, we compared and analyzed carbon emission amounts of all subsystems in common construction and in green construction. Furthermore, strategies and calculation methods involving step-wise increases in carbon prices in a bid to reduce carbon trading cost of construction companies and to lower carbon emission during construction, are discussed.

\section{Calculation of Carbon Emissions at the Materialization Stage}

\subsection{Framework for Estimating Carbon Emissions}

LCA refers to an assessment product, process, or activity [22]. It is a process covering the whole life cycle such as-raw material collection, production, transportation, sales, usage, reuse, maintenance, and final disposal $[23,24]$. LCA is widely used for calculation of carbon emission in energy research and the construction industry [25]. There are two main approaches to LCA - process-based LCA (bottom-up) and LCA (top-down) based on input-output analysis [26]. The former LCA involves a detailed understanding of construction information, such as material use and production efficiency. For this reason, this LCA can be adopted to analyze specific technologies that affect energy consumption during construction [27-29]. In this article, the life cycle assessment method is used to divide a series of states of a building in the materialization stage into different stages. According to GB/T24040-2008 Environmental Management-Life Cycle AssessmentPrinciples and Framework National Standard Understanding, the research can be divided into four stages [30]; shown in Figure 1.

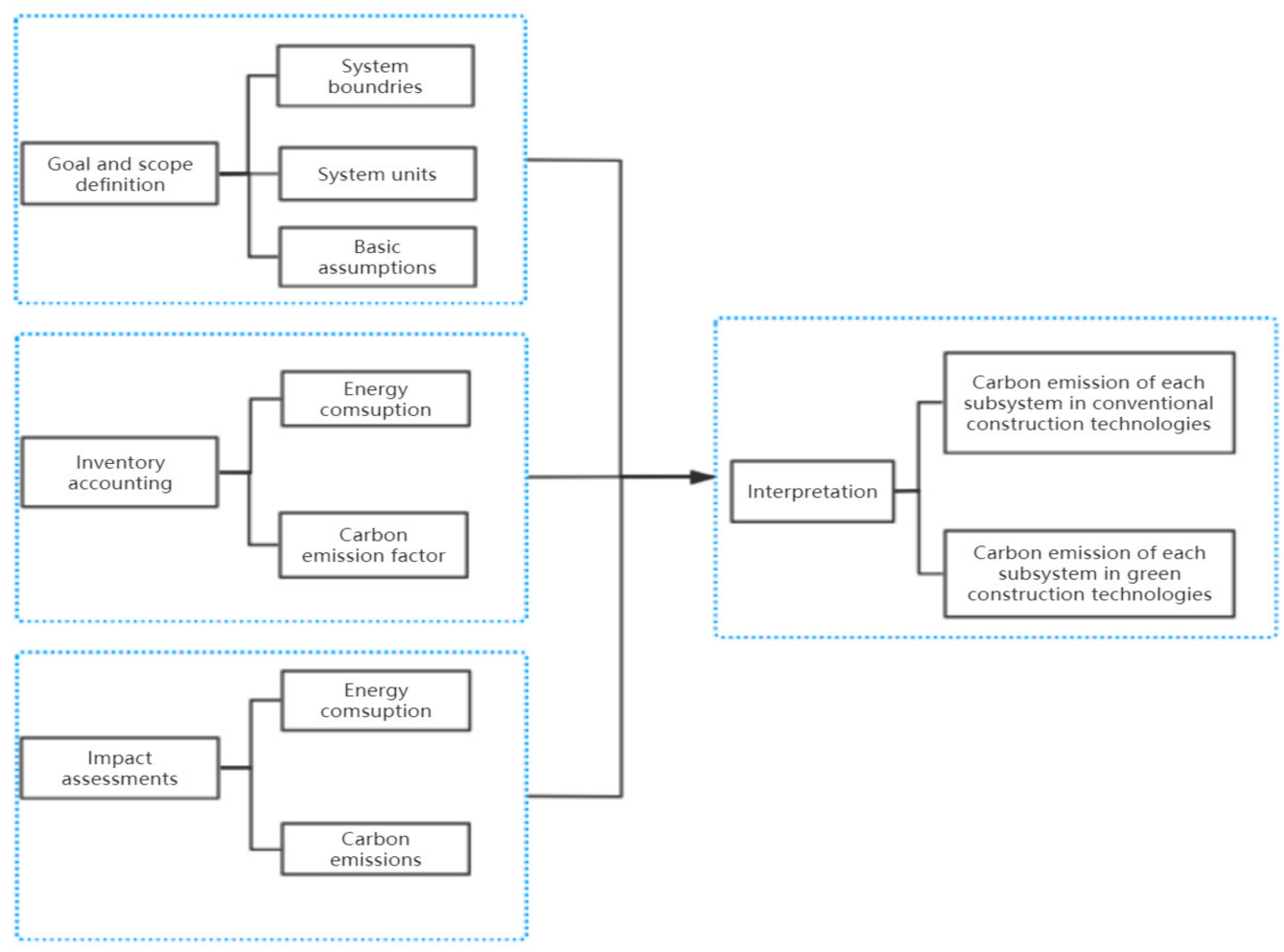

Figure 1. Framework for project-specific estimation of carbon emissions based on life cycle assessment. 
The first stage involves determination of purpose and scope. The system boundary of the construction stage should be determined and relevant data in each link of a production process should be collected. The second stage entails inventory analysis-classification, compilation, and quantification should be conducted on input energy and resources, and output pollution of the targeted products during the whole life cycle. The second stage entails inventory analysis-classification, compilation, and quantification should be conducted on input energy and resources, and output pollution of the targeted products during the whole life cycle. The fourth stage summarizes the results. Data pertaining to the inventory analysis and environmental influence should be summarized and a qualitative carbon price should be determined.

\subsection{Modeling $\mathrm{CO}_{2}$ Emission in Each Subsystem}

$\mathrm{CE}$ refers to emissions of some of the most harmful greenhouse gases, mainly $\mathrm{CO}_{2}$, including $\mathrm{CH}_{4}$ and $\mathrm{N}_{2} \mathrm{O}$. However, because each gas has a different potency, or "warming" effect on the atmosphere, a factor (CE factor) is applied to convert it to the carbon dioxide equivalent [31,32]. The $\mathrm{CE}$ factor refers to the generated amount of greenhouse gas accompanied by the consumption of unit mass material or energy. It is an important parameter representing the CE characteristics of a certain material or energy [33,34]. This article aims to compare the carbon emissions of different construction processes in the building materialization stage, so the measurement of carbon emissions ranges from the entry of building materials to the completion of construction. In this paper, according to the CECS 374:2014 Standard for Measuring, Accounting and Reporting of Carbon Emission from Buildings, the carbon emission factors of common energy are listed Table 1.

Table 1. Carbon emission factors.

\begin{tabular}{|c|c|c|c|c|c|}
\hline Energy & Energy & Carbon Emission Factor & Energy & Energy & Carbon Emission Factor \\
\hline \multirow{4}{*}{ Coal } & Smokeless coal & $98.3 \mathrm{~kg} \mathrm{CO} 2 / \mathrm{GJ}$ & \multirow{4}{*}{ Fuel } & Motor gasoline & $69.3 \mathrm{~kg} \mathrm{CO} / \mathrm{GJ}$ \\
\hline & Coking coal & $94.6 \mathrm{~kg} \mathrm{CO} 2 / \mathrm{GJ}$ & & Kerosene & $71.5 \mathrm{~kg} \mathrm{CO} 2 / \mathrm{GJ}$ \\
\hline & Lignite & $101 \mathrm{~kg} \mathrm{CO} 2 / \mathrm{GJ}$ & & Diesel & $74.1 \mathrm{~kg} \mathrm{CO} 2 / \mathrm{GJ}$ \\
\hline & Charcoal & $107 \mathrm{~kg} \mathrm{CO}_{2} / \mathrm{GJ}$ & & Fuel oil & $77.4 \mathrm{~kg} \mathrm{CO} / \mathrm{GJ}$ \\
\hline \multirow{3}{*}{ Power } & $\begin{array}{l}\text { Regional powergrid in } \\
\text { North China }\end{array}$ & $1.246 \mathrm{~kg} \mathrm{CO} 2 /(\mathrm{kW} \cdot \mathrm{h})$ & \multirow[t]{3}{*}{ Gas } & Natural gas & $56.1 \mathrm{~kg} \mathrm{CO} 2 / \mathrm{GJ}$ \\
\hline & $\begin{array}{l}\text { Regional powergrid in } \\
\text { Central China }\end{array}$ & $0.801 \mathrm{~kg} \mathrm{CO} 2 /(\mathrm{kW} \cdot \mathrm{h})$ & & Coal gas & $44.4 \mathrm{~kg} \mathrm{CO} 2 / \mathrm{GJ}$ \\
\hline & $\begin{array}{l}\text { Regional powergrid in } \\
\text { South China }\end{array}$ & $0.714 \mathrm{~kg} \mathrm{CO} 2 /(\mathrm{kW} \cdot \mathrm{h})$ & & & \\
\hline
\end{tabular}

According to the construction processes and contents at the materialization stage, systematic analysis was adopted to classify the construction system into six subsystemsdecoration engineering, structural engineering, on-site transport, foundation engineering, installation engineering, and construction site facilities. The $\mathrm{CO}_{2}$ emissions from each subsystem was studied, then synthesized into the $\mathrm{CO}_{2}$ emissions at the materialization stage (Figure 2). 


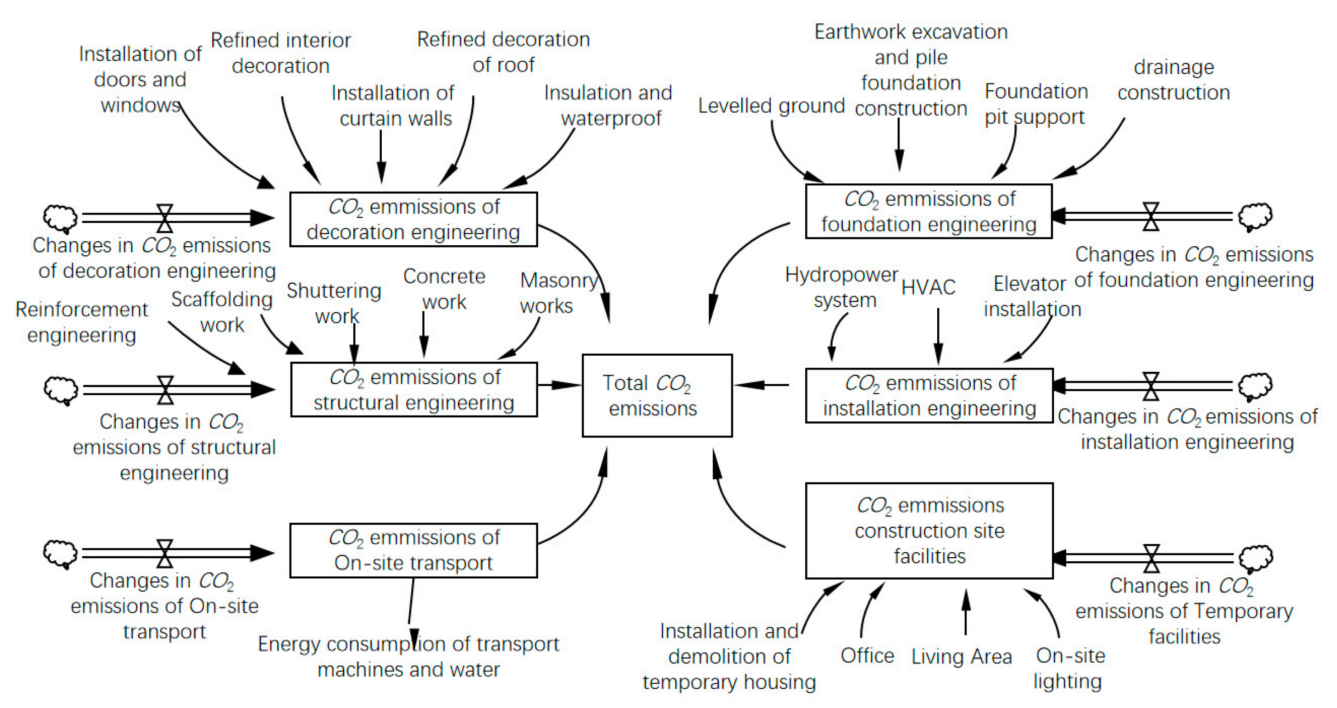

Figure 2. Analysis of $\mathrm{CO}_{2}$ emissions at materialization.

\subsection{Calculation of Carbon Emission at the Materialisation Stage}

At the materialization stage, carbon emission units include transportation of construction materials, components, parts and equipment, operation of construction machines and tools, and the on-site office. At the materialized stage, measurements and calculations could be done according to regulations, as follows [34].

The fuel consumption for the transportation of materials, components, parts and equipment was calculated according to Formula (1).

$$
D_{y s}=\sum_{i=1}^{n} \frac{G_{i}}{Z G_{i}} \times L_{i} \times Q_{s i}
$$

where $D_{y s}$ is the total fuel consumption for the transportation of materials, components, parts, and equipment $(\mathrm{t}) ; G_{i}$ represents the total consumption of materials, components, parts, and equipment of type $i(\mathrm{t}) ; Z G_{i}$ is the average carrying capacity of the vehicle used to transport type $i$ materials, components, parts, and equipment $(\mathrm{t}) ; Q_{s i}$ is the unit fuel consumption of the vehicle used to transport type $i$ materials, components, parts, and equipment $(\mathrm{t} / \mathrm{km})$; and $L i$ is the distance of transportation of type $i$ materials, components, parts, and equipment $(\mathrm{km})$.

Power consumption associated with the operation of the construction machines and tools calculated by Formula (2)

$$
D_{j d x}=\sum_{i=1}^{n} P_{d i} \times T_{d i} \times N_{i}
$$

where $D_{j d x}$ is the total power consumption of construction machines and tools $(\mathrm{kW} \cdot \mathrm{h}) ; P_{d i}$ is the electric power of type $i$ construction machines and tools $(\mathrm{kW}) ; T_{d i}$ is the operating hours of type $i$ construction machines and tools (h); and $N_{i}$ is the number of type $i$ construction machines and tools (units).

Fuel consumption of the operation of the construction machines and tools was calculated by Formula (3).

$$
D_{j x y}=\sum_{i=1}^{n} P_{y i} \times T_{y i} \times N_{i}
$$

where $D_{j x y}$ is the total fuel consumption of construction machines and tools $(\mathrm{t}) ; P_{y i}$ is the average fuel consumption of each type $i$ construction machines and tools per shift $(\mathrm{t} / \mathrm{shift})$; and $T_{y i}$ is the number (shifts) of type $i$ construction machines and tools under operation. 
Water consumption associated with the operation of the construction machines and tools was calculated by Formula (4).

$$
D_{j x s}=\sum_{i=1}^{n} P_{s i} \times T_{s i} \times N_{i}
$$

where $D_{j x s}$ is the total water consumption of construction machines and tools $(\mathrm{t}) ; P_{s i}$ is the average water consumption of each type $i$ construction machines and tools per shift (t/shift); and $T_{s i}$ is the number (shifts) of type $i$ construction machines and tools (time).

Power consumption on the work site of the construction was calculated by Formula (5).

$$
D_{b g d}=\sum_{i=1}^{n} P_{d i} \times T_{d i} \times N_{i}
$$

where $D_{b g d}$ is the total power consumption of on-site office work $(\mathrm{kW} \mathrm{h}) ; P_{d i}$ is the electric power of type $i$ electric equipment for on-site office work $(\mathrm{kW})$; and $T_{d i}$ is the operating hours of type $i$ electric equipment for on-site office work (h).

During the building construction stage, the total carbon emission from buildings was calculated by Formula (6).

$$
\begin{aligned}
& E_{s g}=\sum_{i=1}^{n}\left(D_{s g d i} \times E F_{d}\right)+\sum_{i=1}^{n}\left(D_{s g y i} \times E F_{y}\right)+\sum_{i=1}^{n}\left(D_{s g m i} \times E F_{m}\right)+ \\
& \sum_{i=1}^{n}\left(D_{s g q i} \times E F_{q}\right)+\sum_{i=1}^{n}\left(D_{s g q t i} \times E F_{q t}\right)+\sum_{i=1}^{n}\left(D_{s g s h i} \times E F_{s h}\right)
\end{aligned}
$$

where $E_{s g}$ is the carbon emission from buildings during building construction $\left(\mathrm{tCO}_{2}\right) ; D_{s g d}$ is the power consumption of the unit processes during building construction $(\mathrm{kW}) ; E_{F d}$ is the carbon emission factor of electricity $\left[\mathrm{tCO}_{2} /(\mathrm{kW} \mathrm{h})\right] ; D_{s g y}$ is the fuel consumption of the unit processes during building construction $(\mathrm{t}) ; E F_{y}$ is the carbon emission factor of fuel $\left(\mathrm{tCO}_{2} / \mathrm{t}\right) ; D_{\text {sgm }}$ is the coal consumption of the unit processes during building construction $(\mathrm{t}) ; E F_{m}$ is the carbon emission factor of coal $\left(\mathrm{tCO}_{2} / \mathrm{t}\right) ; D_{s g q}$ is the water consumption of the unit progresses during building construction $(\mathrm{t}) ; E F_{q}$ is the carbon emission factor of coal $\left(\mathrm{tCO}_{2} / \mathrm{t}\right) ; D_{\text {sgsh }}$ is the water consumption of the unit progresses during building construction $(\mathrm{t})$; and $E F_{s h}$ is the water carbon emission factor $\left(\mathrm{tCO}_{2} / \mathrm{t}\right)$.

\section{Overview: A Case Study}

This study took a single teaching complex building in Wuhan as a case to calculate its carbon emission at the materialization stage. This project was located east of Huangjiahu Avenue, Jiangxia District, Wuhan, south of Wangjiaju; west of Dahualing Road, and north of Huyun Road. It included one building for the sales department and exhibition area, one independent shop, seven foreign-style houses, seven villas, four high-rise buildings, and supporting shops along the street. The total construction area was about $206,361 \mathrm{~m}^{2}$, with about $143,800 \mathrm{~m}^{2}$ of above-ground construction and $62,561 \mathrm{~m}^{2}$ of underground construction. Among them, A3 had a total construction area of about $74,496 \mathrm{~m}^{2}$, with an above-ground construction area of about 55,000 $\mathrm{m}^{2}$, the underground construction area of about $19,496 \mathrm{~m}^{2}$. A4 had a total construction area of about $131,865 \mathrm{~m}^{2}$, with an above-ground construction area of about $10,880 \mathrm{~m}^{2}$, and an underground construction area of about $43,065 \mathrm{~m}^{2}$. As shown in Figure 2, the main teaching building in A4 in this case was taken as the subject. The construction of the main teaching building is summarized in Table 2. 
Table 2. Overview of the main building construction.

\begin{tabular}{cc}
\hline Project & Content \\
\hline Construction functions & Teaching buildings; residential houses; office buildings; recreation facility \\
Construction characteristics & With large-scale single floor, diversified functional areas and a U-shaped plan \\
Construction area $\mathrm{m}^{2}$ & 8133 \\
Number of floors & 6 \\
Floor height $\mathrm{m}$ & 3.9 \\
Construction height $\mathrm{m}$ & 25.6 \\
Fire protection & Second class \\
Structure & Frame \\
\hline
\end{tabular}

\section{Discussion}

\subsection{Carbon Emissions during Construction}

Quantity data for all subsystems come from the construction budget. Using the calculation (Section 2.3) mentioned above, the carbon emission of each subsystem was analyzed. With the help of Vensim (proprietary software), the carbon emissions of the six subsystems at the materialization stage were calculated. The results are shown in Table 3.

Table 3. Comprehensive $\mathrm{CO}_{2}$ emission of subsystems (unit- $\mathrm{kg} \mathrm{CO}_{2} \mathrm{eq}$ ).

\begin{tabular}{|c|c|c|c|}
\hline Primary Classification & Secondary Classification & Carbon Emission Of Each Sub-Item & Total Carbon Emission \\
\hline \multirow{5}{*}{ Decoration engineering } & Installation of doors and windows & 2499 & \multirow{5}{*}{42,284} \\
\hline & Installation of curtain walls & 2942 & \\
\hline & Refined decoration of roof & 2015 & \\
\hline & Refined interior decoration & 34,617 & \\
\hline & Insulation and waterproof & 211 & \\
\hline \multirow{5}{*}{ Structural engineering } & Reinforcement work & 54,189 & \multirow{5}{*}{97,954} \\
\hline & Shuttering work & 1367 & \\
\hline & Concrete work & 37,582 & \\
\hline & Masonry work & 4471 & \\
\hline & Scaffolding work & 346 & \\
\hline \multirow[t]{2}{*}{ On-site transport } & $\begin{array}{l}\text { Energy consumption of transport } \\
\text { machines and water }\end{array}$ & 128,237 & \multirow[t]{2}{*}{128,237} \\
\hline & Levelled ground & 685 & \\
\hline \multirow[t]{4}{*}{ Foundation engineering } & $\begin{array}{l}\text { Earthwork excavation and pile } \\
\text { foundation construction }\end{array}$ & 39,373 & \multirow[t]{4}{*}{71,033} \\
\hline & Foundation pit support & 18,623 & \\
\hline & Drainage construction & 12,322 & \\
\hline & Hydropower system & 53,296 & \\
\hline \multirow[t]{3}{*}{ Installation engineering } & HVAC & 33,423 & \multirow[t]{3}{*}{86,850} \\
\hline & Elevator installation & 131 & \\
\hline & $\begin{array}{l}\text { Installation and demolition of } \\
\text { temporary housing }\end{array}$ & 5156 & \\
\hline \multirow{3}{*}{ Construction site facilities } & Office & 33,630 & \multirow[t]{3}{*}{69,778} \\
\hline & Living area & 27,473 & \\
\hline & On-site lighting & 3519 & \\
\hline
\end{tabular}

\subsection{Effect of Green Construction on Building's Carbon Emission}

The building stage usually calls for a great amount of materials, energy, and water resources. Reducing resource consumption and increasing resources utilization is an effective method of carbon emission reduction. According to the "Green Construction Guidelines" [35] issued by the Ministry of Construction of the People's Republic of China, the specific framework of green construction is shown in Figure 3: 


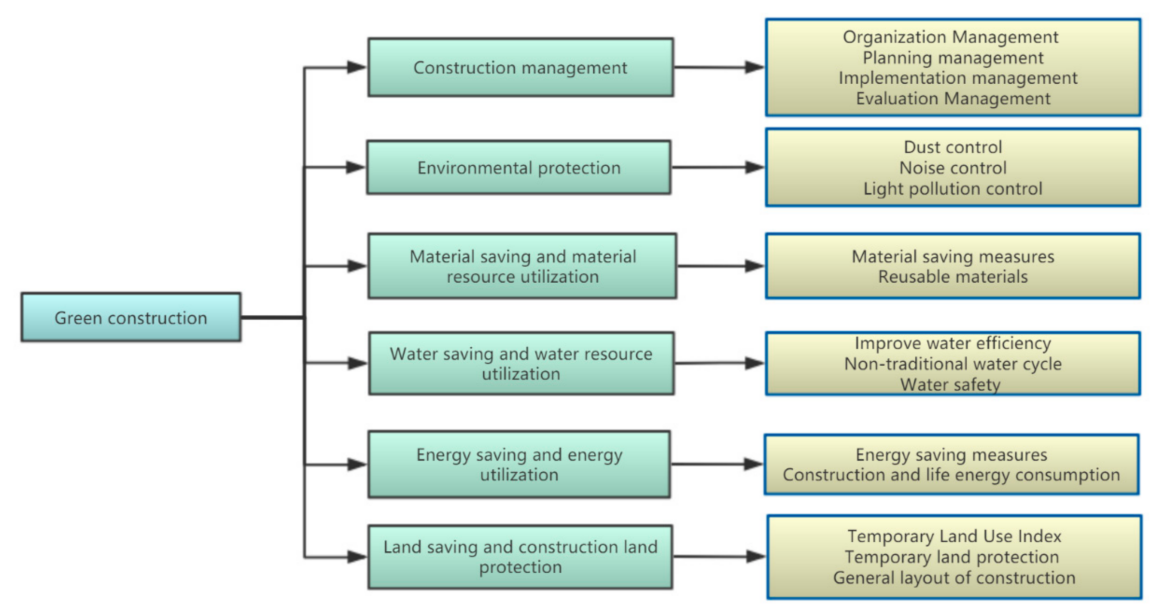

Figure 3. Green construction frame diagram.

For this project, major measures were taken for its green construction, as follows. First, some measures to reduce energy consumption during the construction caused by lighting and heating, during operation, were taken. These measures included reducing operation energy consumption of lighting by unleashing the energy conservation potential of lighting. Lighting energy consumption during construction could decrease by more than $5 \%$, by replacing traditional lamps with new energy-saving LED and fluorescent lamps $[36,37]$. Second, renewable or clean energy was used in the project. Third, to reduce water consumption, it could install low-flow devices and appliances in water-using equipment and reuse rainfall or construction waste water, where possible. Fourth, by using green building materials, components of a building and its parts, the equipment transport efficiency could be increased. Fifth, secondary transport was conducted as little as possible to reduce the operational energy consumption of construction machines and tools in on-site transport as well as carbon emissions during construction [38]. Optimization such as that achieved in energy conservation and green construction could reduce carbon emissions at materialization. Optimization through carbon emission calculations and Vensim provided the carbon emissions of all subsystems (Table 4).

Table 4. Comprehensive $\mathrm{CO}_{2}$ emission of subsystems after optimization (unit- $\mathrm{kgCO}_{2} \mathrm{eq}$ ).

\begin{tabular}{|c|c|c|c|}
\hline Primary Classification & Secondary Classification & Carbon Emission of Each Sub-Item & Total Carbon Emission \\
\hline \multirow{5}{*}{ Decoration engineering } & Installation of doors and windows & 2463 & \multirow{5}{*}{34,256} \\
\hline & Installation of curtain wall & 2673 & \\
\hline & Refined decoration of roof & 198 & \\
\hline & Refined interior decoration & 28,711 & \\
\hline & Insulation and waterproof & 211 & \\
\hline \multirow{5}{*}{ Structural engineering } & Reinforcement work & 49,322 & \multirow{5}{*}{87,496} \\
\hline & Shuttering work & 1367 & \\
\hline & Concrete work & 32,561 & \\
\hline & Masonry work & 4121 & \\
\hline & Scaffolding work & 125 & \\
\hline \multirow[t]{2}{*}{ On-site transport } & $\begin{array}{c}\text { Energy consumption of transport machines } \\
\text { and water }\end{array}$ & 99,869 & 99,869 \\
\hline & Site levelling & 596 & \multirow{4}{*}{64,212} \\
\hline \multirow[t]{3}{*}{ Foundation engineering } & $\begin{array}{l}\text { Earthwork excavation and pile } \\
\text { foundation construction }\end{array}$ & 34,512 & \\
\hline & Foundation pit support & 17,863 & \\
\hline & Drainage construction & 11,241 & \\
\hline \multirow{3}{*}{ Installation engineering } & Hydropower system & 46,231 & \multirow{3}{*}{77,876} \\
\hline & HVAC & 31,521 & \\
\hline & Elevator installation & 124 & \\
\hline \multirow{4}{*}{ Construction site facilities } & Installation and demolition temporary housing & 4213 & \multirow{4}{*}{62,901} \\
\hline & Office & 31,254 & \\
\hline & Living area & 24,571 & \\
\hline & On-site lighting & 2863 & \\
\hline
\end{tabular}




\subsection{Analysis of Carbon Emission Differences under Different Construction Programs}

Figure 4 shows the carbon emission proportion of each subsystem under common construction. During construction, on-site transport and structural engineering accounted for $26 \%$ and $20 \%$ of the total carbon emission, respectively. The huge consumption of fuel, materials, and water in on-site transport and structural engineering meant that the carbon emissions from on-site transport and structural engineering accounted for almost half of the total carbon emissions.

The green construction mentioned in Section 4.2 shows that power consumption can be reduced by a wide use of energy-saving lamps and the enhancement of indoor lighting [39]. Secondary transport, large tower cranes, and other handling machines should be used as little as possible for on-site transport. In structural engineering, the carbon emissions of steel reinforcement and concrete accounted for the vast majority of the total emissions. Most of these carbon emissions resulted from the use of steel processing machines, and concrete mixing and pumping machines. Therefore, emission reduction could be achieved by implementing better on-site management, processing and utilizing materials in an efficient manner, and avoiding unnecessary energy waste. For example, as shown in Figure 5, carbon emission of on-site transport among all subsystems under green construction techniques was the largest, accounting for about $23 \%$ of the total emissions.

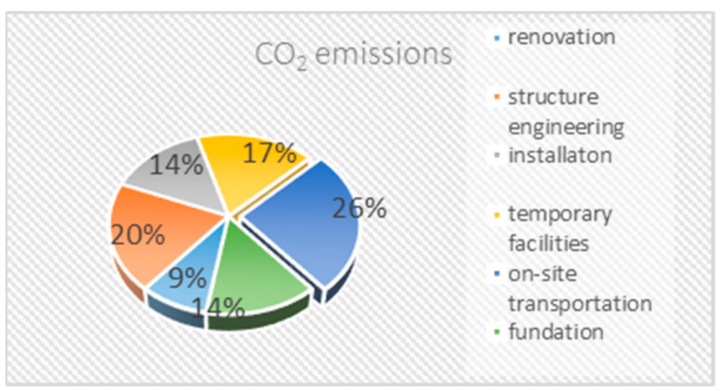

Figure 4. $\mathrm{CO}_{2}$ emissions from sub-projects under common construction.

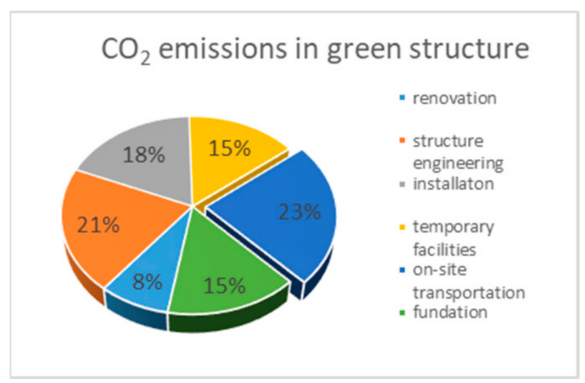

Figure 5. $\mathrm{CO}_{2}$ emissions in green construction.

Figure 6 shows that green construction did better than common construction in terms of emission reduction form subsystems. To clarify the differences between carbon emissions of subsystems under these two construction programs, carbon emission differences per unit area of all subsystems were calculated (Table 5). As shown in Table 5, among all subsystems under the green construction protocols, on-site transport saw the largest reduction in carbon emissions, followed by structural engineering (foundation engineering had the smallest reduction). 


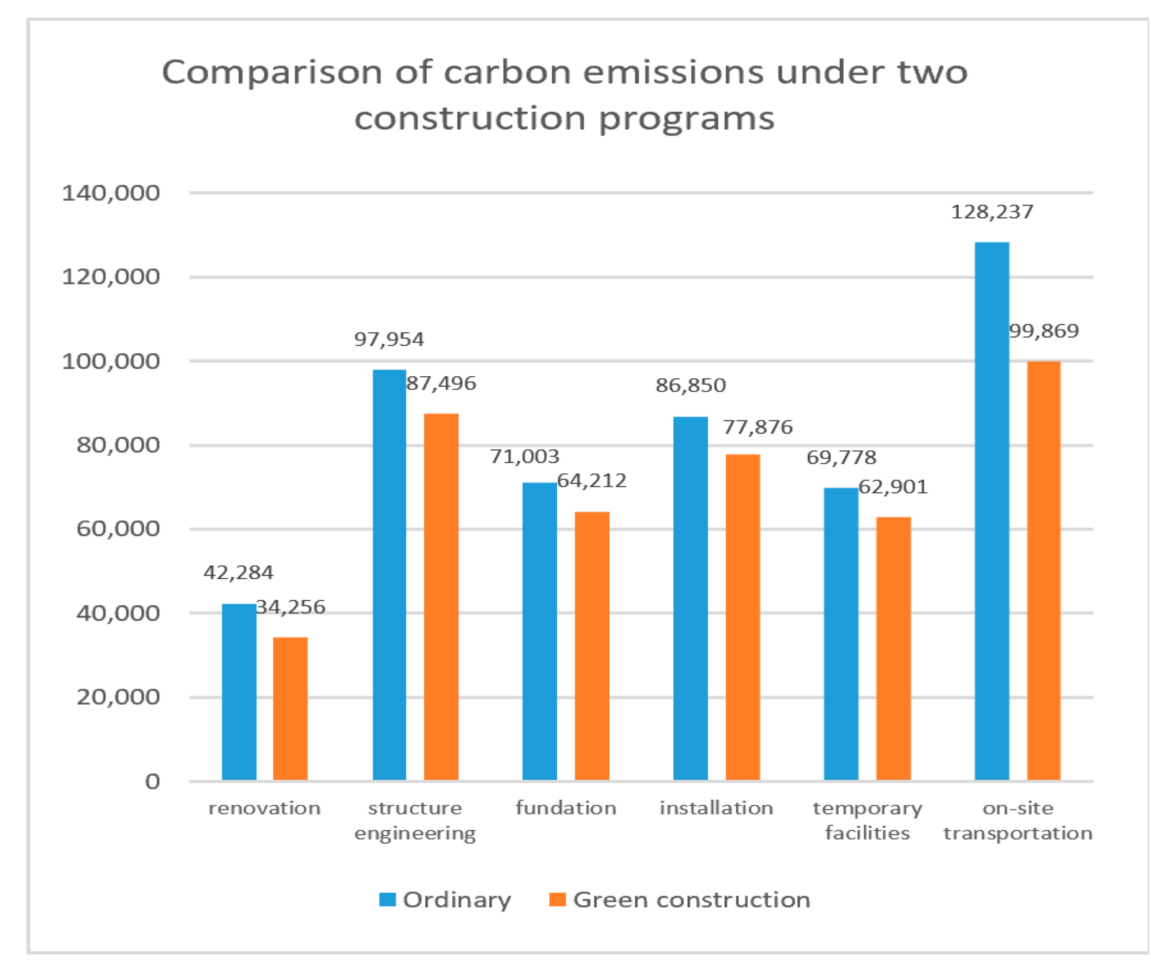

Figure 6. Comparison of carbon emissions under two construction programs (unit- $\mathrm{kgCO}_{2} \mathrm{eq}$ ).

Table 5. The difference between common construction and green construction in carbon emission of subsystems (unit$\mathrm{kg} \mathrm{CO} 2 \mathrm{eq})$.

\begin{tabular}{ccc}
\hline Primary Classification & Carbon Emission Difference & Carbon Emission Difference Per Unit Area \\
\hline Decoration engineering & 8028 & 0.987 \\
structural engineering & 10,458 & 1.286 \\
On-site transport & 8974 & 1.103 \\
Foundation engineering & 6877 & 0.846 \\
Installation engineering & 28,368 & 3.488 \\
Construction site facilities & 6791 & 0.835 \\
\hline
\end{tabular}

\subsection{Effect of Transportation Engineering Based on Different Buildings on Carbon Emissions}

There are certain differences in the carbon emission composition of different building types during the materialization stage. Compared with residential buildings, schools have larger bays, while factories are better. Therefore, in terms of steel reinforcement engineering, buildings with large bays are cut-off by steel bars. Energy consumption is reduced to a certain extent. In addition, the height of teaching buildings is generally around 6 floors, and most residential buildings are high-rise buildings, so the carbon emissions generated by vertical transportation engineering are not the same; and the construction environment is not the same. The impact of carbon emissions during the construction phase cannot be ignored. Therefore, the study counts different types of buildings in the central region such as Jiangxi, Hunan, Hubei, and other places, to compare and determine the proportion of carbon emissions from on-site transportation in the entire construction process to prove the feasibility of the study. A bar chart (Figure 7) shows the carbon emission proportions of all subsystems during construction. 


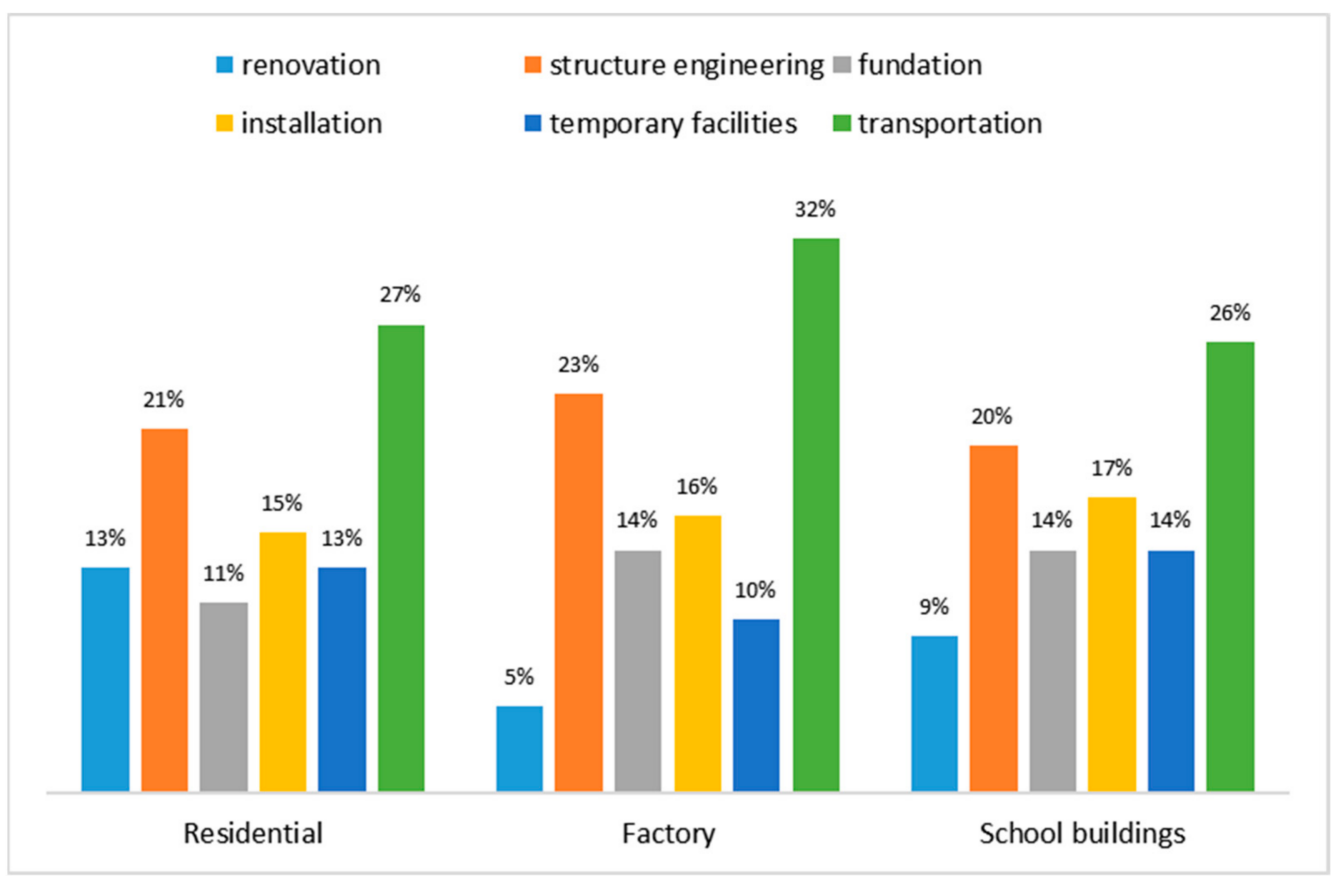

Figure 7. Percentages of carbon emissions from construction of various subsystems.

As shown in Figure 7, proportions of carbon emissions from some subsystems in different items of buildings are different. However, proportions of carbon emissions from transportation engineering remain the largest despite different items of buildings, so energy reduction in transportation works play a significant and considerable role in carbon emission reduction during the whole construction process. Therefore, the key to solving urgent problems lies in guiding construction companies to start carbon emission reduction from transportation engineering perspectives.

\section{Discussion and Conclusions}

\subsection{Effect of Green Construction Based on Subsystems on Carbon Trading Prices}

In national construction and social progress, it is inevitable to bring a lot of pollution to the environment, and greenhouse gas emissions are one of them. In order to alleviate global warming, it is necessary to make corresponding policies, such as the use of laws to limit greenhouse gas emissions, so there is a trading market for carbon emission. The trading market for carbon emission rights regards carbon emission rights as commodities and promotes emission reduction through economic means. The establishment of a carbon emission rights market in China is in its infancy, so setting reasonable carbon trading prices would boost the implementation of energy conservation and emission reduction policies [40]. During construction and under the carbon trading mechanism, energy reduction potential of subsystems should be considered and should also offer targeted carbon emission prices and encourage enterprises to adopt green construction technologies.

Taking this project (a teaching building) as an example, the methods to realize the aforementioned goals were discussed.

First, carbon emission differences between common construction and green construction were calculated. The carbon emission difference for each subsystem was divided by the carbon emission difference of the whole project during construction. Percentages of carbon emission difference from all subsystems were then calculated, as shown in Formula (7).

$$
\theta_{i}=\left(P_{i}-L_{i}\right) / D
$$

In Formula (7), $\theta_{i}$ is the percentage of a subsystem's carbon emission difference of the total carbon emissions difference under two different construction programs. $P_{i}$ 
is the carbon emission from common construction; $L_{i}$ is the carbon emission from green construction, and $D$ is the sum of carbon emission difference between common construction and green construction (Figure 6).

As shown in Figure 8, in this case, the carbon emission difference between common construction and green construction per unit area accounted for $41 \%$ of the carbon emission difference of on-site transport. While the carbon emission differences of other projects occupied a relatively small proportion, of about $10 \%$ to $15 \%$, therefore, under the building's carbon trading mechanism, enterprises could be guided to lay their emphasis of emission reduction on on-site transport works with the largest emission reduction potential afforded by increasing carbon trading prices of on-site transport. Meanwhile, carbon trading prices of other projects were decreased to balance the price hike for on-site transport. On the basis of another report [41], we proposed a step-wise coefficient of increasing carbon price for each subsystem:

$$
f_{i}=\beta \times\left(B_{i}-c\right)+100 \% c=\frac{1}{n} * 100 \%
$$

where $f_{i}$ is the step-wise coefficient of increasing carbon price for price adjustment in type-i subsystem; $\beta$ is the coefficient of adjustment in total price; $B$ is the ratio of carbon emission differences per unit area of type $i$ subsystem; and $n$ is the number of subsystems.

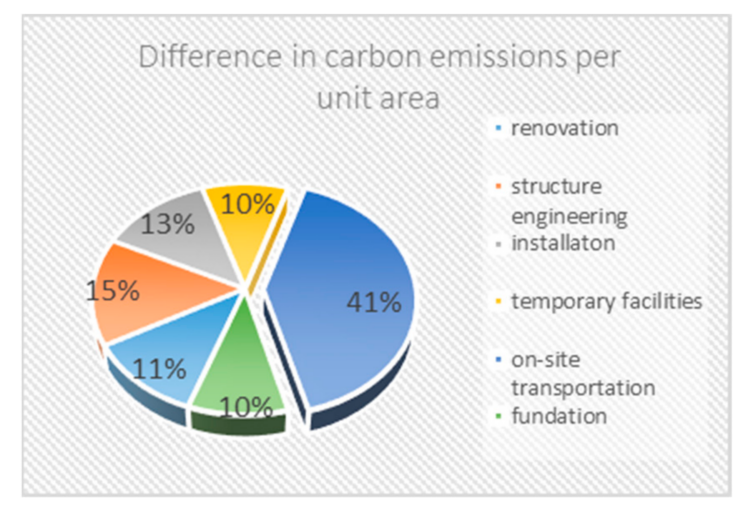

Figure 8. Difference in carbon emissions per unit area.

The value of $\beta$ (coefficient of adjustment in total price terms) is related to the construction company's expected benefit brought by emission reduction- $\beta$ varies from 0 to $1 /\left(c-\min B_{i}\right)$, in which $\min B_{i}$ represents the minimum ratio of carbon emission differences per unit area of type $i$ subsystem.

By adjusting carbon trading prices of all subsystems in accordance with Formula (8), the total carbon trading price remains unchanged. Meanwhile, subsystems with a huge potential for emission reduction offer a higher carbon price, stimulating enterprises to prioritize these projects for energy conservation and emission reduction. This would lower the construction company's trading cost and realize its goal of reducing total carbon emission during construction.

For example, in this program, the construction company expected a halving of carbon emission rights trading, as shown in the following formula:

$$
\left[\beta\left(41 \%-\frac{1}{6}\right)+100 \%\right] \times 41 \%=50 \%
$$

Then, we found that $\beta=0.9$ and the price adjustment coefficient was found by using Formula (8). The results are shown in Table 6. 
Table 6. Coefficient of step-wise increases in carbon price in each subsystem.

\begin{tabular}{cc}
\hline Primary Classification & Coefficient of Increasing Carbon Price (\%) \\
\hline On-site transport & 121.9 \\
Foundation engineering & 94 \\
Decoration engineering & 94.9 \\
Structural engineering & 98.5 \\
Installation engineering & 96.7 \\
Construction site facilities & 94 \\
\hline
\end{tabular}

The results showed that carbon trading price of on-site transport increased to $121.9 \%$ of the original price while carbon prices of other subsystems decreased to 94 to $98.5 \%$ of the original price. Therefore, to improve their economic benefits accruing therefrom, construction companies should emphasize transportation emissions reductions.

To conclude, this policy of gradient prices could guide construction companies to adopt high-efficiency technologies for emission reduction. This would further fulfil the target of carbon emission reduction in buildings, at a national level, and deliver the social benefits brought by emission reduction.

\subsection{Conclusions}

The construction industry was always a key industry for energy conservation and emission reduction, mainly because buildings generate a large amount of greenhouse gases during the materialization stage, and these gases can be controlled by improving the construction process. Green construction not only reduces carbon emissions, but also improves the problems of dust, noise pollution, and light pollution. Based on the LCA framework, the research used system dynamics to divide the materialization stage into six subsystems, and calculates the corresponding carbon emissions of each subsystem under ordinary construction and green construction. The results showed that during the materialization stage of the building, on-site transport generated the most carbon emissions and the carbon emissions reduced by green construction were also the greatest. Therefore, in the subsystem, the focus of energy conservation and emission reduction was placed on the transportation project, improving the efficiency of energy saving and emission reduction of construction enterprises, to a large extent. A carbon price gradient formula was proposed to increase the carbon trading price in the on-site transport, and guide the main force of emission reduction to on-site transport. Under a building-type of carbon trading mechanism, it would be better for resource allocation and market control to increase carbon trading prices of on-site transport, implementing step-wise increases in carbon price in all subsystems and guiding construction companies towards technological adjustment and green construction. It should be noted that the relevant government should implement green construction into actual projects, so as to truly achieve the goal of emission reduction, and carbon emission rights trading is only a means to promote emission reduction. This research can be used as a reference for relevant government in the formulation of relevant carbon emission trading systems. This study only focused on the materialization stage of a building, however, the operation and demolition stage also generate a considerable amount of carbon emission. In future, more studies need to focus on the other stages throughout the life cycle of a building.

Author Contributions: S.Z. operated the thermal conductivity tests and analyzed the data. Z.G. wrote this manuscript. Y.D. and J.D. finished the model. J.L. and J.F. supervised the study and contributed to the manuscript writing. All authors discussed the results. All authors have read and agreed to the published version of the manuscript.

Funding: This work was supported by Natural Science Foundation of China (Grant nos. 51662008 and 51968022), and a Key R \& D Project of Jiangxi Province (Grant no. 20171BBG70078). 
Institutional Review Board Statement: Ethical review and approval were waived for this study because the institutions of the authors who participated in data collection do not require IRB review and approval.

Conflicts of Interest: The authors declare no conflict of interest.

\section{References}

1. UNFCCC. Adoption of the Paris Agreement; United Nations Office at Geneva: Geneva, Switzerland, 2015.

2. Working Group I. The IPCC 6th Assessment Report; 1-4 IPCC: Stockholm, Sweeden, 2018.

3. Xie, R.; Zhao, G.; Zhu, B.; Lai, M. Regional Transfer of Haze Pollutants Embodied in China's Foreign Trade and Factors Affecting it: A GERIO-based Empirical Analysis. Emerg. Mark. Financ. Trade 2016, 52, 1335-1347. [CrossRef]

4. Ma, X.M.; Cai, Y. Report on China's Low-Carbon Finance Development; Peking University Press: Beijing, China, $2014 ;$ pp. 6-11. (In Chinese)

5. Jin, F.J.; Ma, L.; Xu, D. Environmental stress and optimized path of industrial development in the Yellow River Basin. Res. Sci. 2020, 42, 127-136. [CrossRef]

6. Tong, Y.; Yin, Y.; Qian, L.; An, J.L. Analysis of the Characteristics of Hazy Phenomena in Nanjing Area. China Environ. Sci. 2011, $27,584-588$.

7. Zhou, S.; Ding, Y.; Wang, Z.P.; Dong, J.L.; She, A.M.; Wei, Y.Q.; Li, R.G. Weathering of roofing insulation materials under multi-field coupling conditions. Materials 2019, 12, 3348. [CrossRef] [PubMed]

8. Huo, T.; Ren, H.; Zhang, X.; Cai, W.; Feng, W.; Zhou, N.; Wang, X. China's energy consumption in the building sector: A Statistical Yearbook-Energy Balance Sheet based splitting method. J. Clean. Prod. 2018, 185, 665-679. [CrossRef]

9. Zhang, Z.H.; Wu, X. A Building Environmental Impact Assessment System Based on LCA. Urban Environ. Urban Ecol. 2004, 9 , 27-29. (In Chinese)

10. Zhang, D.Y.; Zhang, L.X. Research Progress on Carbon Source Emission Estimation Methods. Inn. Mong. For. Sci. 2005, 1, 20-23. (In Chinese)

11. Li, B.; Li, Y.X.; Wu, B.; Fu, F.F. Research on Carbon Emission Measurement Model of Construction. J. Inf. Technol. Civ. Eng. 2011, 2, 5-10. (In Chinese)

12. Yu, P.; Chen, X.Q.; Ma, L.Y. Review on Studies of Life Cycle Carbon Emission from Residential Buildings. Build. Sci. 2011, 27, 9-12. (In Chinese)

13. Zhang, Z.H.; Shang, C.J.; Qian, K. Evaluation of Carbon Emission in Building's Life Cycle. Constr. Econ. 2010, 2, 44-46. (In Chinese)

14. Ximenes, F.A.; Grant, T. Quantifying the Greenhouse Benefits of the Use of Wood Products in Two Popular House Designs in Sydney, Australia. Int. J. Life Cycle Assess. 2013, 18, 891-908. [CrossRef]

15. Wang, J.J.; Zhao, W.; Wang, S.L. Study on Calculation Methods of Carbon Emissions of Buildings during the Construction. Build. Sci. 2014, 2, 8-12. (In Chinese)

16. Zhang, X.; Shen, L.; Zhang, L. Life Cycle Assessment of the Air Emissions during Building Construction Process: A Case Study in Hong Kong. Renew. Sustain. Energy Rev. 2013, 17, 160-169. [CrossRef]

17. Gong, X.Z.; Nie, Z.R.; Wang, Z.H.; Cui, S.; Gao, F.; Zuo, T. Life Cycle Energy Consumption and Carbon Dioxide Emission of Residential Building Designs in Beijing: A Comparative Study. J. Ind. Ecol. 2012, 16, 576-587. [CrossRef]

18. Available online: www.tanpaifang.com (accessed on 8 January 2021).

19. Gao, Y.; Liu, X.J. Identify and the Value of Green Building Carbon Emissions Based on Cost-effectiveness. J. Xi'an Univ. Archit. Technol. 2016, 48, 755-759.

20. Zhao, R.; Zhou, X.; Min, X.F. Game Theoretical Analysis on Purchase of Carbon labelled Product Based on System Dynamics. J. Syst. Sci. 2021, 29, 111-114.

21. Haites, E. Carbon Taxes and Greenhouse Gas Emissions Trading Systems: What have we learned? Clim. Policy 2018, 18, 955-966. [CrossRef]

22. Peuportier, B.; Thiers, S.; Guiavarch, A. Eco-design of buildings using thermal simulation and life cycle assessment. J. Clean. Prod. 2013, 39, 73-78. [CrossRef]

23. Yang, Z.; Da, Y.; Shan, H.; Guo, S. Modelling of Energy Consumption and Carbon Emission from the Building Construction Sector in China, A Process-based LCA Approach. Energy Policy 2019, 134, 1-9.

24. Lin, L.; Jiang, Y.; Yan, D.; Peng, C. Analysis of Energy Consumption in Building Construction and $\mathrm{CO}_{2}$ Emission. Energy China 2015, 37, 7-14.

25. Sartori, I.; Hestnes, A. Energy use in the life cycle of conventional and low energy buildings: A review article. Energy Build. 2007, 39, 249-257. [CrossRef]

26. Monahan, J.; Powell, J.C. An Embodied Carbon and Energy Analysis of Modern Methods of Construction in Housing: A Case Study Using a Life Cycle Assessment Framework. Energy Build. 2011, 43, 179-188. [CrossRef]

27. Säynäjoki, A.; Heinonen, J.; Junnila, S.; Horvath, A. Can life-cycle assessment produce reliable policy guidelines in the building sector? Environ. Res. Lett. 2017, 12, 013001. [CrossRef]

28. Su, X.; Zhang, X. A Detailed Analysis of the Embodied Energy and Carbon Emissions of Steel-construction Residential Buildings in China. Energy Build. 2016, 119, 323-330. [CrossRef] 
29. Buyle, M.; Braet, J.; Audenaert, A. Life Cycle Assessment in the Construction Sector: A Review. Renew. Sustain. Energy Rev. 2013, 26, 379-388. [CrossRef]

30. China National Institute of Standardization. GB/T 24040-2008; Environmental Management_Life Cycle Assessment—Principles and Framework; Standard Press of China: Beijing, China, 2008. (In Chinese)

31. Yildiz, I.; Caliskan, H. Energetic and exergetic carbon dioxide equivalents and prices of the energy sources for buildings in Turkey. Environ. Prog. Sustain. Energy 2018, 37, 912-925. [CrossRef]

32. De Wolf, C.; Pomponi, F.; Moncaster, A. Measuring embodied carbon dioxide equivalent of buildings: A review and critique of current industry practice. Energy Build. 2017, 140, 68-80. [CrossRef]

33. Gao, Y.; Li, Z.D.; Zhang, H.; Yu, B.; Wang, J.Y. A carbon emission analysis model for prefabricated construction based on LCA. J. Eng. Manag. 2018, 32, 30-34. (In Chinese)

34. Ni, J.Q.; Heber, A.J.; Diehl, C.A.; Lim, T.T. Se-structures and environment: Ammonia, hydrogen sulphide and carbon dioxide release from pig manure in under-floor deep pits. J. Agric. Eng. Res. 2000, 77, 53-66. [CrossRef]

35. Guidelines for Green Construction; Construction Quality 223; Ministry of Construction of the People's Republic of China: Beijing, China, 2007. (In Chinese)

36. Junnila, S.; Horvath, A.; Guggemos, A.A. Life-cycle assessment of office buildings in Europe and the United States. J. Infrastruct. Syst. 2006, 12, 10-17. [CrossRef]

37. Wang, L. Study on Application of Green Energy-saving Construction Technology in Building Construction. Energy Conserv. Environ. Prot. 2018, 31, 43-44. (In Chinese)

38. Thormark, C. Environmental Analysis of a Building with Reused Building Materials. Int. J. Low. Energy Sust. Build. 2000, 1, 1-18.

39. Venkatarama Reddy, B.V.; Jagadish, K.S. Embodied Energy of Common and Alternative Building Materials and Technologies. Energy Build. 2003, 35, 129-137. [CrossRef]

40. Chen, X.L.; Liu, X.B. Research on Carbon Emission Regulation Policy of Building Sector Based on Carbon Tax /Subsidy: Taking EU's Building Sector Carbon Emission Policy for Example. Urban Dev. Stud. 2013, 10, 21-27. (In Chinese)

41. Hu, R.; Chen, L.; Zhu, J.L. Complexity of Airlines' Dynamic Price Competition with Carbon Emission Trading. J. Transp. Syst. Eng. Inf. Technol. 2018, 18, 6-12. (In Chinese) 